\title{
GMP-140, a Platelet $\alpha$-Granule Membrane Protein, Is Also Synthesized by Vascular Endothelial Cells and Is Localized in Weibel-Palade Bodies
}

\author{
Rodger P. McEver," Jay H. Beckstead, ${ }^{\ddagger}$ Kevin L. Moore, " Linda Marshall-Carlson, ${ }^{5}$ and Dorothy F. Bainton ${ }^{\ddagger}$ \\ *St. Francis Medical Research Institute and Department of Medicine, University of Oklahoma Health Sciences Center, and the \\ Cardiovascular Biology Research Program, Oklahoma Medical Research Foundation, Oklahoma City, Oklahoma 73104; ${ }^{\ddagger}$ Department \\ of Pathology, University of California School of Medicine, San Francisco, California 94143; and ${ }^{\S}$ Department of Genetics and \\ Development, Columbia University College of Physicians and Surgeons, New York, New York 10032
}

\begin{abstract}
We used an immunoperoxidase procedure to examine the tissue distribution of the platelet $\alpha$-granule membrane protein, GMP-140. In addition to its presence in megakaryocytes and platelets, GMP-140 antigen was found in vascular endothelial cells of diverse human organs, but it was not detected in other types of secretory cells. [ $\left.{ }^{35} \mathrm{~S}\right] \mathrm{Cysteine-labeled} \mathrm{human} \mathrm{umbilical}$ vein endothelial cells synthesized a GMP-140 molecule containing complex $\boldsymbol{N}$-linked oligosaccharides similar to those previously demonstrated in platelets and the megakaryocytic HEL cell line. Using an immunogold procedure on frozen thin sections of endothelial cells, we found GMP-140 antigen to be localized to membranes of electron-dense storage granules. In double-label experiments there was colocalization of GMP-140 with vWf, indicating that these granules are Weibel-Palade bodies. When endothelial cells were stimulated with histamine, GMP-140 rapidly redistributed to the plasma membrane. Immunoassays of cell lysates indicated that, relative to total cell protein, less GMP-140 is present in human umbilical vein endothelial cells than in platelets. The restricted expression of GMP-140 in secretory granules of platelets and endothelium suggests that it has a specific function in the vascular system rather than a general role related to inducible secretion.
\end{abstract}

\section{Introduction}

GMP-140 is a platelet $\alpha$-granule membrane protein of $M_{\mathrm{r}}$ 140,000 that redistributes to the plasma membrane during platelet activation and degranulation (1-5). The protein is cysteine-rich and contains several complex $N$-linked oligosaccharide chains (6). Protease accessibility studies suggest that most of the mass of GMP-140 is exposed on the extracytoplasmic face of the membrane (6). The function of GMP-140 is not known and its distribution in cells other than platelets

A preliminary report of this study was presented at the Annual Meeting of the American Society of Hematology, Washington, DC, 6 December 1987, and was published in abstract form (1987. Blood. 70[Suppl 1]:355a).

Address correspondence to Dr. McEver, Department of Medicine, University of Oklahoma Health Sciences Center, 825 N.E. 13th Street, Oklahoma City, OK 73104-5073. 1989.

Received for publication 15 July 1988 and in revised form 3 March

J. Clin. Invest.

(C) The American Society for Clinical Investigation, Inc.

0021-9738/89/07/0092/08 \$2.00

Volume 84, July 1989, 92-99 and megakaryocytes (7) has not been established. If the protein is located in storage granules of diverse cells, it might have a conserved function related to inducible secretion. Alternatively, restriction of GMP-140 expression to secretory cells found in blood would suggest a function specific to the vascular system.

In this study we used an immunoperoxidase procedure to examine the distribution of GMP-140 in a variety of human tissues. In addition to its presence in megakaryocytes and platelets, GMP-140 antigen was detected in vascular endothelial cells but not in a variety of other cell types examined. We have documented the synthesis of GMP-140 in endothelial cells and have localized the protein to the membranes of Weibel-Palade bodies, the intracellular storage granules for $\mathrm{vWf}$.

\section{Methods}

Antibodies. The MAbs S12 $(1,3)$ and W40 (6), both directed against GMP-140, and monospecific rabbit polyclonal antiserum to GMP-140 (3) were prepared as described previously. Tab, a MAb to platelet glycoprotein Ilb, has been previously characterized (8). MAbs were used as purified IgG in $0.20 \mathrm{M}$ sodium phosphate, $\mathrm{pH} 7.4$, and $0.15 \mathrm{M}$ sodium chloride. Affinity-purified polyclonal rabbit anti-human vWf antibodies were obtained from Dako Corp. (Santa Barbara, CA).

Immunoperoxidase procedures. Immunoperoxidase detection of antigens in plastic-embedded sections of human tissues was performed as described previously (7).

Culture of endothelial cells. Human umbilical vein endothelial cells were isolated and grown by a modification of the procedure of Jaffe et al. (9). The cells were cultured in medium 199 (K. C. Biologicals, Kansas City, MO) containing $25 \mathrm{mM}$ Hepes buffer supplemented with $100 \mathrm{U} / \mathrm{ml}$ penicillin, $100 \mu \mathrm{g} / \mathrm{ml}$ streptomycin, $2 \mathrm{mM}$ glutamine (K. C. Biologicals), $20 \%$ fetal bovine serum (K. C. Biologicals), $50 \mu \mathrm{g} / \mathrm{ml}$ heparin, and $60 \mu \mathrm{g} / \mathrm{ml}$ endothelial cell growth supplement (Collaborative Research Inc., Lexington, MA). Only primary or first-passage cultures at or near confluence were used. Some primary cultures for frozen thin sections (see below) were a gift from Dr. Israel Charo and Dr. William Isenberg (the Gladstone Foundation, University of California at San Francisco).

Metabolic labeling of endothelial cells. GMP-140 was immunoprecipitated from $\left[{ }^{35} \mathrm{~S}\right]$ cysteine-labeled lysates of human endothelial cells and analyzed by SDS-PAGE as described previously in studies of HEL cells (6), except that the endothelial cells were grown in $75-\mathrm{cm}^{2}$ flasks instead of cluster dishes. As a control, ${ }^{125}$ I-labeled GMP-140 from human platelets was analyzed concurrently (6). Incubation of immunoprecipitates with endo- $\beta$ - $N$-acetylglucosaminidase $\mathrm{H}$ (endo $\mathrm{H})^{1}$ was performed as described previously (6).

Immunocytochemical techniques on frozen thin sections. Monolayers of human umbilical vein endothelial cells were fixed in 4 or $8 \%$

1. Abbreviations used in this paper: Endo $\mathrm{H}$, endo- $\beta-N$-acetylglucosaminidase $\mathrm{H}$; ER, endoplasmic reticulum. 
paraformaldehyde in Nakane's buffer, embedded in $2.1 \mathrm{M}$ sucrose, and frozen. Sections were prepared as previously described (3). The primary antibody was polyclonal antiserum to GMP-140 used at a dilution of 1:100. The immunogold probe, goat anti-rabbit IgG-gold (GAR-5 [5 nm] or GAR-10 [10 nm]; Janssen Pharmaceutica, Beerse, Belgium) was used at a dilution of 1:50. Nonimmune rabbit serum was used in place of the primary antiserum to act as a control. A double-labeling experiment to simultaneously localize GMP-140 and vWf was performed using protein A, as described by Slot and Geuze (10). Polyclonal antiserum to GMP-140 was applied and labeled with 5-nm gold particles coupled to protein A (protein A-5; Janssen Pharmaceutica). $0.05 \mathrm{mg} / \mathrm{ml}$ free protein A was then added. Next, polyclonal antibodies to $\mathrm{vWf}$ (1:100 dilution) were applied, followed by $10-\mathrm{nm}$ gold particles coupled to protein A (protein A-10; Janssen Pharmaceutica). The protein A-colloidal gold reagents were used for the double-label studies because they gave more precise localization due to the $1: 1$ binding ratio with primary antibody. The antibody-gold complex (GAR-5 or GAR-10) was used in other experiments because of its increased sensitivity due to binding of multiple secondary antibodies to the same primary antibody; this binding property, however, resulted in some clumping of gold particles leading to less precise antigen localization.

In some experiments confluent monolayers were prewarmed to $37^{\circ} \mathrm{C}$ in HBSS containing $10 \mathrm{mM}$ Hepes, $\mathrm{pH} 7.4$, then incubated with $10^{-4} \mathrm{M}$ histamine in the same buffer at $37^{\circ} \mathrm{C}$ for $1 \mathrm{~min}$. The histamine-stimulated cells were then rapidly washed, fixed, and processed for immunocytochemistry with GAR-5 or GAR-10.

Preparation of cell extracts for immunoassay. Platelet-rich plasma (11) was centrifuged at $500 \mathrm{~g}$ for $20 \mathrm{~min}$ and the platelet pellet was resuspended to the original volume with $0.145 \mathrm{M} \mathrm{NaCl}, 5 \mathrm{mM}$ Pipes, 4 $\mathrm{mM} \mathrm{KCl}, 1 \mathrm{mM} \mathrm{MgCl}, 0.5 \mathrm{mM} \mathrm{Na}_{2} \mathrm{HPO}_{4}$, and $42 \mathrm{nM} \mathrm{PGE}_{1}$, pH 6.8. After measuring the cell count on a Coulter counter (model ZBI; Coulter Electronics Inc., Hialeah, FL) the suspension was again centrifuged at $500 \mathrm{~g}$ for $20 \mathrm{~min}$. The pellet was then extracted with $50 \mathrm{mM}$ Tris- $\mathrm{HCl}, \mathrm{pH} 7.5,1 \%$ Triton X-100, $100 \mu \mathrm{M}$ leupeptin, and $90 \mu \mathrm{M}$ PMSF (extract buffer) at a final concentration of $2 \times 10^{9}$ platelets per milliliter. Endothelial cells from one confluent $75-\mathrm{cm}^{2}$ flask were washed three times with HBSS, then collected by scraping the cells into $10 \mathrm{ml}$ of HBSS. After centrifugation of the suspension at $500 \mathrm{~g}$ for 20 min the cell pellet was resuspended in $1 \mathrm{ml}$ of extract buffer. Both cell extracts were centrifuged at $12,000 \mathrm{~g}$ for $5 \mathrm{~min}$ to remove insoluble material. The protein concentrations of the supernatants were then determined with a protein assay (Bio-Rad Laboratories, Richmond, CA) using BSA as standard.

Quantitation of GMP-140 by ELISA. A sandwich ELISA technique developed by Dr. Sandor Shattil (University of Pennsylvania, Philadelphia, PA) was used. $100 \mu \mathrm{l}$ of $\mathrm{W} 40\left(10 \mu \mathrm{g} / \mathrm{ml}\right.$ in $66 \mathrm{mM} \mathrm{NaHCO}{ }_{3}, \mathrm{pH}$ 9.0) was added to individual wells of microtiter plates Immulon-II; (Dynatech Laboratories, Inc., Alexandria, VA) overnight at $4^{\circ} \mathrm{C}$. After three washes with PBS, pH 7.4, containing $0.1 \%$ Tween (all subsequent washes were also performed with this buffer) the plates were blocked by addition to each well of $200 \mu \mathrm{l}$ PBS, $1 \%$ BSA, and $0.02 \%$ sodium azide for $2 \mathrm{~h}$ at room temperature and then washed three more times. Serial dilutions in $0.1 \mathrm{M} \mathrm{NaCl}, 0.02 \mathrm{M}$ Tris- $\mathrm{HCl}, 1 \%$ Triton X-100, $\mathrm{pH} 7.5$, of cell extract or purified GMP-140 (6) were placed in triplicate wells (100 $\mu \mathrm{l} /$ well) and incubated for $2 \mathrm{~h}$ at room temperature. After an additional three washes, $100 \mu \mathrm{l}$ of biotin-conjugated $\mathrm{S} 12$ (12) at 10 $\mu \mathrm{g} / \mathrm{ml}$ in PBS and $0.1 \%$ Tween was added to each well and incubated for $2 \mathrm{~h}$ at room temperature. After three more washes horseradish peroxidase-congugated streptavidin (Amersham International, Amersham, UK) diluted 1:1,000 in PBS and 0.1\% Tween was placed in each well $(100 \mu \mathrm{l} /$ well) and incubated for $30 \mathrm{~min}$ at room temperature. After an additional three washes $100 \mu \mathrm{l}$ of 2,2'azino-di-[3-ethylbenzthiazoline sulfonate] peroxidase substrate (Kirkegaard \& Perry Laboratories, Inc., Gaithersburg, MD) was added to each well. After incubation at room temperature for $15 \mathrm{~min}$ the absorbance at $405 \mathrm{~nm}$ was measured with a Vmax kinetic microplate reader interfaced to Softmax software (Molecular Devices Corp., Palo Alto, CA). GMP-140 antigen levels in nanograms/milliliter were obtained from a standard curve (log
GMP-140 vs. absorbance at $405 \mathrm{~nm}$ ), constructed using serial dilutions of purified human GMP-140. The assay was sensitive to $25 \mathrm{ng} / \mathrm{ml}$.

\section{Results}

Tissue distribution of GMP-140. A variety of human tissues, summarized in Table I, were examined for the presence of GMP-140 antigen with a sensitive avidin-biotin immunoperoxidase procedure. GMP-140 was detected in bone marrow megakaryocytes (Fig. $1 a$ and reference 7), platelets (Fig. 1, $a$ and $e$ ), and endothelial cells lining blood vessels of multiple organs (Fig. 1, $b-e$ and Table I). Endothelial cell GMP-140 was detected by the MAb S12 and by polyclonal antibodies to GMP-140. Nonimmune rabbit serum and MAbs of irrelevant specificity did not label endothelial cells. These negative controls did demonstrate occasional weak staining of other cell types, probably because of endogenous biotin. Only staining above this background was considered positive. The GMP-140 antigen visualized in endothelium was not due to adherence of platelets, since Tab, MAb that recognizes the platelet-specific glycoprotein IIb $(8,13)$, stained platelets in the lumen of blood vessels but did not label endothelial cells (Fig. $1 f$ ). In contrast, antibodies to glycoprotein IIIa, which is present in both platelets and endothelial cells, stained both cell types (7).

Endothelial cell GMP-140 antigen was detected in greatest abundance in small veins and venules, although patchy distribution was occasionally noted in small arteries, arterioles, and very rarely in capillaries. The endothelial distribution of GMP-140 demonstrated some differences from that previously reported for thrombomodulin, an endothelial cell membrane cofactor for protein C activation (14). Unlike thrombomodulin, GMP-140 antigen was detected in some blood vessels of brain and in high endothelial cells of lymph nodes (Fig. $1 d$ ) but was not found in lymphatics or in syncytiotrophoblast lining cells of placenta.

\section{Table I. Immunoperoxidase Localization of GMP-140}

\begin{tabular}{ll}
\hline Organs displaying endothelial GMP-140 & \multicolumn{1}{c}{ Other findings } \\
\hline Adrenal & \\
Brain & \\
Breast & \\
Colon & \\
Ductus deferens & \\
Duodenum & Glomeruli (-) \\
Kidney & Central veins (+) \\
Liver & \\
Lung & High endothelial venules (+) \\
Lymph node & Endocardium (+) \\
Myocardium & \\
Pancreas & \\
Parathyroid & \\
Pituitary & Syncytiotrophoblast (-) \\
Placenta & \\
Salivary gland & \\
Skin & \\
Soft tissues & \\
Spleen & \\
Stomach & \\
Testis & \\
Uterus & \\
\end{tabular}



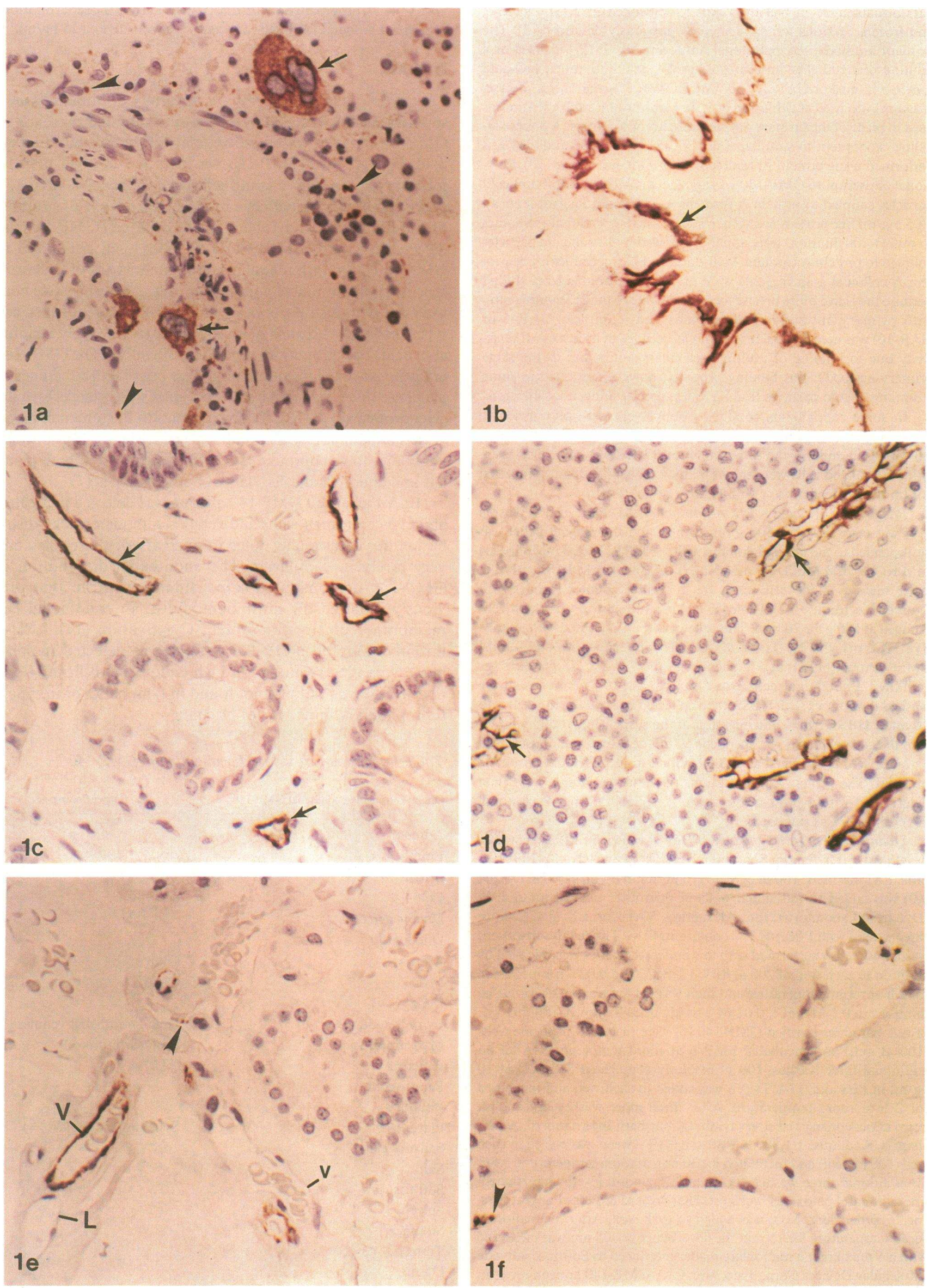


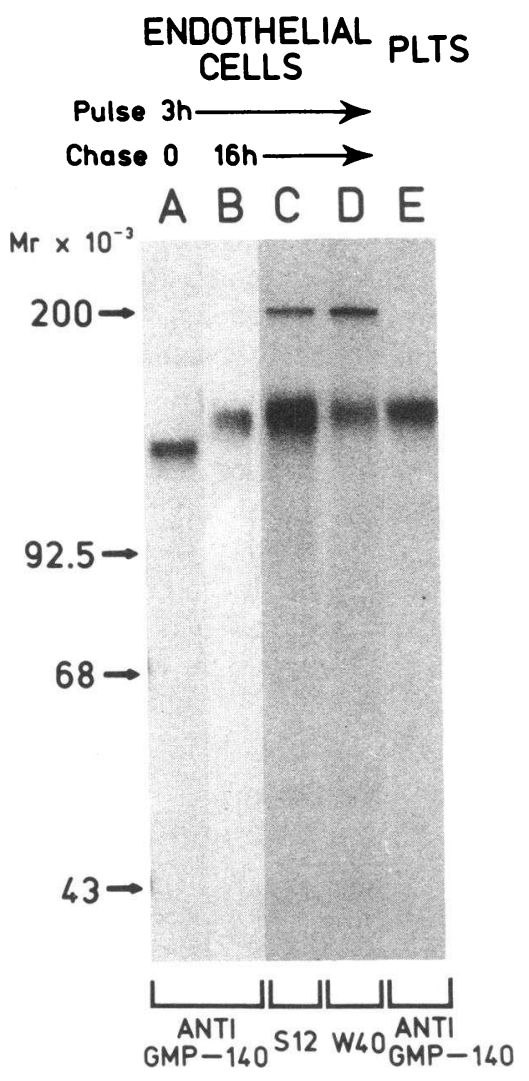

Figure 2. Biosynthesis of GMP-140 in endothelial cells. Human umbilical vein endothelial cells were pulsed for $3 \mathrm{~h}$ in medium containing $\left[{ }^{35} S\right]$ cysteine, then chased in nonradioactive medium for the indicated times. Triton X-100 lysates were immunoprecipitated with polyclonal antibodies to GMP-140 or with the MAb S12 or W40. Immunoprecipitates were analyzed by SDS-PAGE in a $7 \%$ polyacrylamide gel followed by fluorography. For comparison, ${ }^{125}$ I-labeled platelet GMP-140 was immunoprecipitated and analyzed by electrophoresis in lane $E$. The labeled bands of $M_{\mathrm{r}} 200,000$ seen in lanes $C$ and $D$ probably represent myosin nonspecifically precipitated from cell extracts and were not seen in other experiments.
GMP-140 antigen was detected only in megakaryocytes, platelets, and vascular endothelial cells. The protein was not found in other cells in peripheral blood (not shown) or bone marrow (Fig. 1 a). Moreover, we did not detect antigen in a variety of other cells that contain storage granules whose contents are released after stimulation of the cell (Table I). These included adrenal gland, pituitary, pancreas, brain, breast, and salivary gland.

Biosynthesis of GMP-140 in endothelial cells. To determine whether endothelial cells synthesize GMP-140, we immunoprecipitated lysates of $\left[{ }^{35}\right.$ S $]$ cysteine-labeled human umbilical vein endothelial cells with antibodies to GMP-140 and examined the immunoprecipitates by SDS-PAGE and fluorography. Fig. 2 demonstrates that in lysates of cells pulsed for $3 \mathrm{~h}$, polyclonal antibodies to GMP-140 (lane $A$ ) immunoprecipitated a precursor molecule that migrated faster than platelet GMP-140 (lane E). The MAb S12 and W40 also precipitated this molecule (not shown). When the labeled cells were chased for $16 \mathrm{~h}$ before lysis in medium containing unlabeled cysteine, the antibodies precipitated an endothelial cell protein that co-

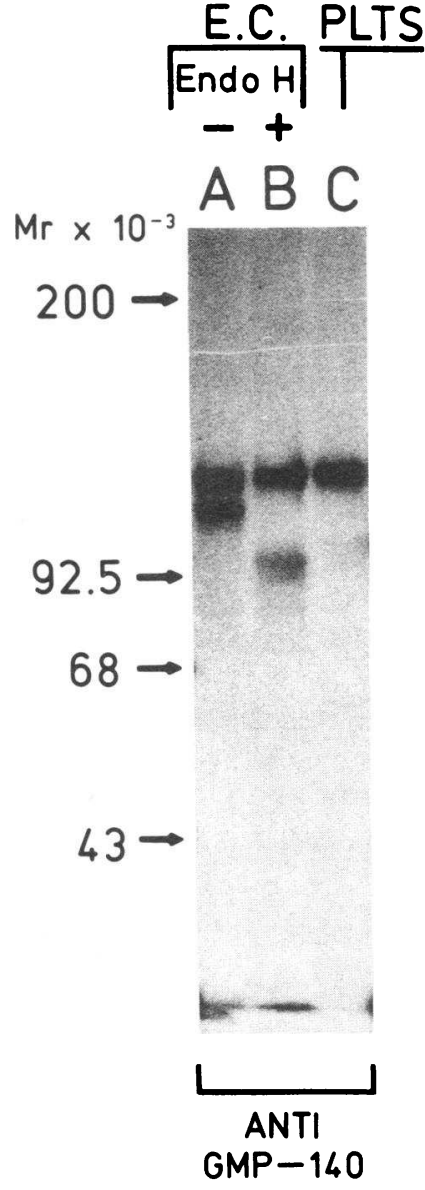

Figure 3. Sensitivity of the endothelial cell GMP-140 precursor to digestion with endo $H$. Endothelial cells were pulsed for $3 \mathrm{~h}$ with $\left[{ }^{35} \mathrm{~S}\right]-$ cysteine, then chased for $3 \mathrm{~h}$ in nonradioactive medium. Cell lysates were immunoprecipitated with polyclonal antibodies to GMP-140, and the immunoprecipitates were treated with endo $\mathrm{H}$ (lane $B$ ) or with control buffer (lane $A$ ) before SDS-PAGE and fluorography. For comparison, ${ }^{125} \mathrm{I}$-labeled platelet GMP-140 was analyzed by electrophoresis in lane $C$.

migrated with platelet GMP-140 (lanes $B-D$ ). We have previously shown that HEL cells, which share features of megakaryocytes (15), synthesize a $125-\mathrm{kD}$ precursor of GMP-140 which is converted to a $140-\mathrm{kD}$ form that comigrates with platelet GMP-140 (6). The precursor contains $N$-linked oligosaccharides of the high mannose type which are sensitive to cleavage with the enzyme endo $\mathrm{H}(16)$, while the mature molecule in both HEL cells and platelets contains complex $N$ linked chains that are not cleaved by endo $\mathrm{H}$. The mobilities of the two forms of GMP-140 precipitated from endothelial cells suggested a similar form of posttranslational processing. To test this possibility, we examined the ability of endo $H$ to remove oligosaccharide chains from GMP-140 in endothelial cells. Cells were pulsed for $3 \mathrm{~h}$ with $\left[{ }^{35} \mathrm{~S}\right]$ cysteine, then chased for $3 \mathrm{~h}$ in nonradioactive medium. Under these conditions both the precursor and mature forms of GMP-140 were immunoprecipitated. Immunoprecipitates were incubated with endo $\mathrm{H}$ or with control buffer, then examined by SDS-PAGE and fluorography. As shown in Fig. 3, endo $H$ decreased the $M_{\mathrm{r}}$ of the precursor but did not change the $M_{\mathrm{r}}$ of the mature

Figure 1. Photomicrographs of plastic embedded human tissues incubated with the MAb S12 to GMP-140 (a-e) or the MAb Tab to glycoprotein IIb $(f)$ and labeled with an avidin-biotin-peroxidase-3,3' diaminobenzidine procedure. Brown reaction product is present at sites of antigen localization. (a) A normal human bone marrow shows strong staining in megakaryocytes (arrows) and platelets (arrowheads). Other hematopoietic cells are completely negative. (b) A human umbilical vein shows a strong brown reaction confined to the endothelial cells (arrow). (c) Small vessels within the gastric mucosa are strongly labeled (arrows). (d) High endothelial cells in the lymph node show strong staining for GMP-140 (arrows). (e) Small vessels in the thyroid gland demonstrate considerable variability in staining. A venule $(V)$ shows strong staining while an adjacent lymphatic $(L)$ and a second venule $(v)$ show no staining. Note that two platelets are identifiable in the lumen of a negative venule (arrowhead). $(f)$ The same thyroid tissue incubated with antibody to glycoprotein Ilb shows staining of platelets within vessels (arrowheads), but no staining of the endothelium. All figures counterstained with hematoxylin. $\times \mathbf{4 0 0}$. 
molecule. These findings suggest that endothelial cells, like HEL cells and presumably megakaryocytes, synthesize a precursor of GMP-140 that contains high mannose $N$-linked oligosaccharides. The high mannose chains are then converted to the complex type in the Golgi apparatus.

Subcellular localization of GMP-140 in endothelial cells. In unstimulated platelets, GMP-140 is localized in the membranes of $\alpha$-granules $(3,4)$. To determine whether endothelial cell GMP-140 is also located in secretory storage granules, we used an immunogold procedure on frozen thin sections of unstimulated human umbilical vein endothelial cells. Immunogold label was found in intracellular electron-dense granules, mainly along the membranes, but was not found on the plasma membrane (Figs. 4, $a$ and $b$, and 5). Smaller amounts of label were also found in fragmented endoplasmic reticulum (ER) and on Golgi cisternae membranes. Some of the granules containing immunogold marker for GMP-140 had images suggestive of the tubular, periodic matrix characteristic of Weibel-Palade bodies, the organelles where vWf is concentrated and converted into high molecular weight mul- timers (17-21). However, the frozen thin section procedure did not provide optimal preservation to allow classification of the granules as Weibel-Palade bodies by morphologic criteria. We therefore performed double-label experiments with antibodies to both GMP-140 and vWf, as described in Methods. The smaller gold label for GMP-140 was again detected mainly along the membranes of granules, while the larger gold label for vWf was more widely distributed over the matrix of the granules (Fig. $4 c$ ). As with GMP-140, the major concentration of vWf was in granules with lesser amounts detected in fragmented ER and Golgi cisternae. The colocalization of both GMP-140 and vWf to the same granules establishes that GMP-140 is also located in Weibel-Palade bodies.

vWf stored in Weibel-Palade bodies is rapidly secreted from endothelial cells stimulated with agonists such as thrombin (22), phorbol myristate acetate (20), histamine (23), and complement proteins C5b-9 (24). This suggests that after endothelial cell activation GMP-140 might redistribute from the membranes of Weibel-Palade bodies to the plasma membrane in a manner analogous to its redistribution to the cell surface
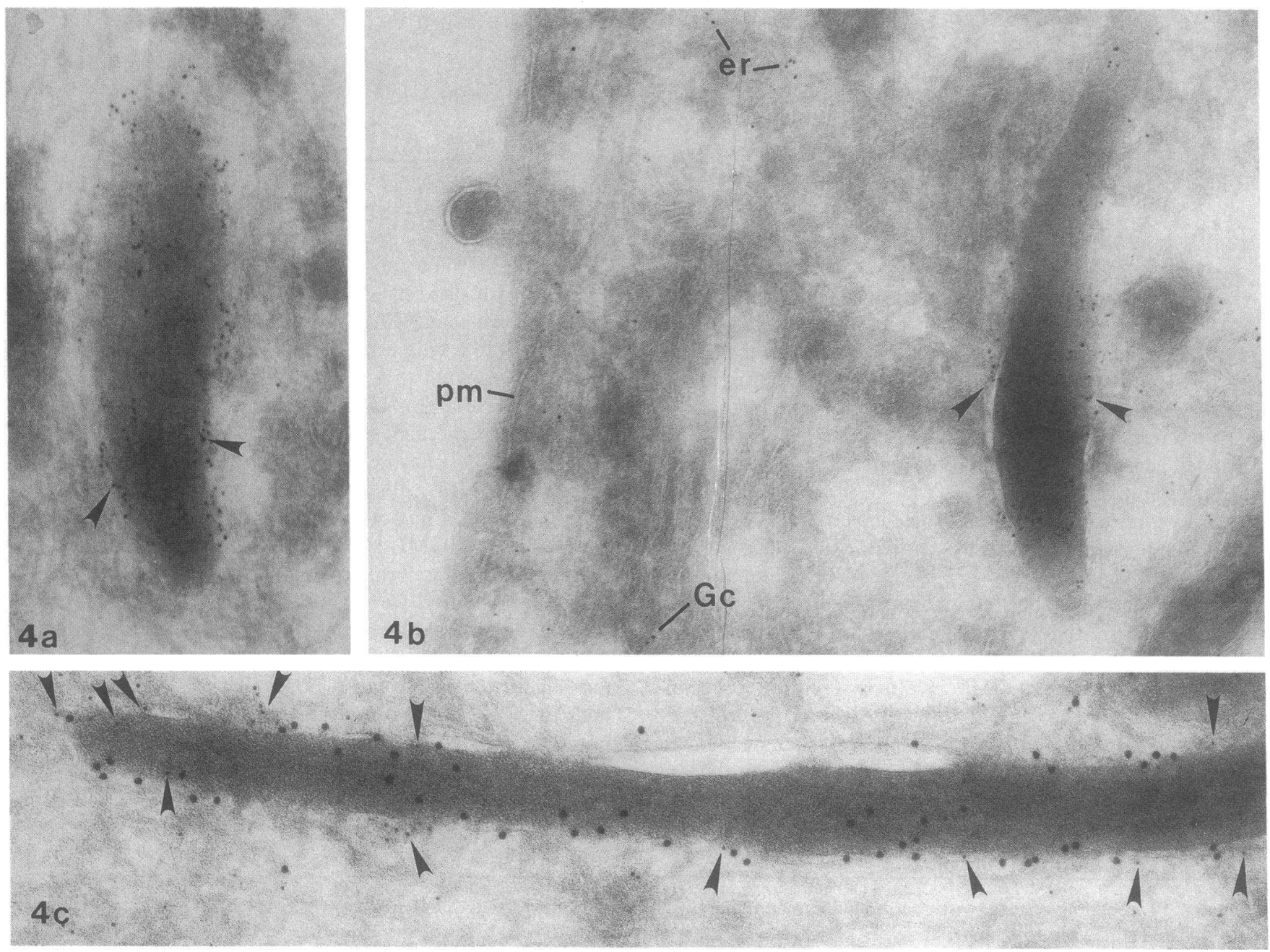

Figure 4. ( $a$ and $b$ ) Electron micrographs of unstimulated cultured human umbilical vein endothelial cells incubated with polyclonal antibodies to GMP-140 on a frozen thin section and labeled with GAR-5. The majority of the intracellular gold particles are found near the membranes of elongated granules (arrows). Other scant labeling can be found on Golgi membranes $(G c)$ and fragmented ER (er) but none is found on the plasma membrane $(p m) .(a) \times 72,000 ;(b) \times 69,000$. (c) Frozen thin section of endothelial cells double labeled with antibodies to GMP-140 followed by protein A-5 (small gold particles marked by arrows) and then with antibodies to vWf followed by protein A-10 (large gold particles). The presence of vWf indicates that these elongated granules are Weibel-Palade bodies. $\times 125,000$. 


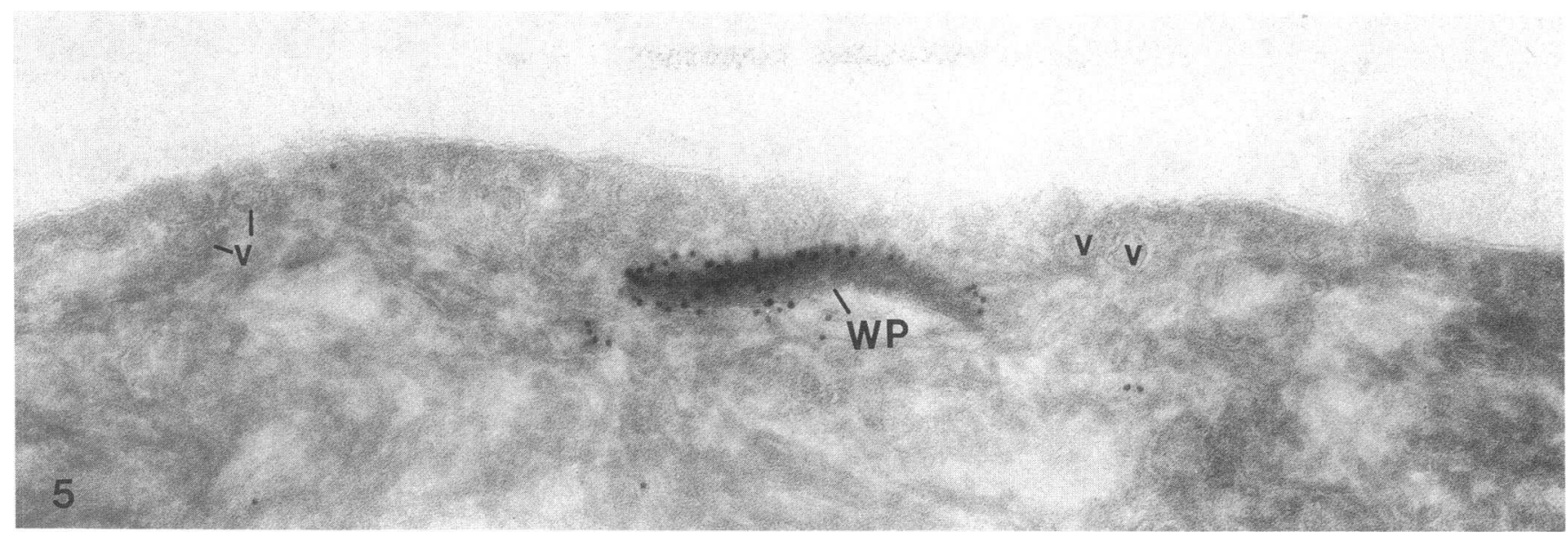

Figure 5. Electron micrograph of an unstimulated human umbilical vein endothelial cell incubated with polyclonal antibodies to GMP-140 on a frozen thin section, and labeled with GAR-10. Note that endocytic vesicles $(v)$ and the plasma membrane have only low levels of immunogold labeling while the intracellular Weibel-Palade body $(W P)$ is densely labeled. $\times 81,000$.

after platelet activation (1-5). To examine this possibility, we stimulated endothelium for 1 min with histamine, then immediately fixed the cells and determined the location of GMP-140 by the immunogold procedure. As shown in Fig. 6 , the surface of stimulated endothelial cells contained increased numbers of microvilli, and immunogold label for GMP-140 was seen on the plasma membrane and frequently on the microvilli themselves. Under these experimental conditions, most of the redistribution of GMP-140 was toward the apical surface.

Quantitation of GMP-140. The relative amounts of GMP-140 present in lysates of human platelets and umbilical vein endothelial cells were examined by an ELISA procedure. Platelets contained $1.66 \pm 0.40 \mathrm{ng}$ of GMP-140/ $\mu$ g of cell protein (mean $\pm \mathrm{SD}, n=4$ ), whereas endothelial cells contained $0.126 \pm 0.046 \mathrm{ng}$ of GMP-140/ $\mu \mathrm{g}$ of cell protein (mean $\pm \mathrm{SD}, n$ $=4)$. This corresponded to $0.166 \%$ of the total platelet protein and $0.0126 \%$ of the total endothelial cell protein. Therefore, relative to total cell protein, platelets contained 13 -fold more GMP-140 than endothelial cells.

\section{Discussion}

Our findings indicate that GMP-140 is present in vascular endothelial cells as well as platelets and their precursor cells, megakaryocytes. The only other well-characterized protein whose expression is limited to platelets and endothelial cells is vWf (25-27). Several additional proteins, for example glycoprotein IIIa (28), protein $S(29,30)$, and thrombospondin (31), are found in both cell types but are also synthesized in other tissues. GMP-140 was not detected in a variety of other cells examined, including those with secretory storage granules. $\mathrm{Al}$ though the avidin-biotin immunoperoxidase antigen detection procedure is sensitive, we cannot exclude the presence of small quantities of GMP-140 in such cells not detected by our methods. However, the apparent restriction to platelets and endothelial cells suggests that GMP-140 has a function specific to the vascular system rather than a general role common to many kinds of secretory cells. Immunoassays of cell lysates indicated that, relative to total cell protein, there is less GMP-140 in human umbilical vein endothelial cells than in platelets. The relatively smaller amount of endothelial GMP-140, however, does not necessarily indicate that its function is less important than its counterpart in platelets. Furthermore, we do not know if the amount of GMP-140 measured in umbilical vein endothelial cells by ELISA is comparable to that in small veins and venules, where antigen was most frequently found by immunohistochemistry.

Like the platelet protein $(3,4)$, endothelial cell GMP-140 is localized in the membranes of secretory storage granules. In endothelium, these granules are the Weibel-Palade bodies, well-characterized organelles where high molecular weight multimers of vWf are stored until their release by a variety of endothelial cell agonists (17-24). The inducible secretion of vWf is thought to occur during fusion of membranes of Weibel-Palade bodies with the plasma membrane (32). This process is supported by the immunogold labeling experiments which demonstrated rapid redistribution of GMP-140 to the plasma membrane of histamine-stimulated cells. Elsewhere, we have quantitated the inducible endothelial redistribution of GMP-140 and examined its kinetics in detail $(24,33)$. These studies, in conjunction with the current report, suggest that antibodies to GMP-140 will prove useful as markers for early activation events in endothelial cells, similar to their previously documented utility for assessing platelet activation in vivo and in vitro $(12,34-36)$.

Since GMP-140 rapidly shifts from the membranes of secretory granules to the surface of stimulated platelets and endothelial cells, it may function as an important receptor at sites of inflammation or vascular injury, where these cells are likely to be activated. We have recently determined the primary structure of GMP-140 by cDNA cloning and protein sequencing (37). The protein contains a number of discrete domains, including a lectinlike region, an epidermal growth factor domain, and nine tandem consensus repeats related to those found in complement-binding proteins. These domains suggest that GMP-140 might have functions related to cell adhesion and inflammation. This possibility is supported by the remarkable structural similarity of GMP-140 to ELAM-1, a cytokine-inducible endothelial cell receptor that mediates the adhesion of neutrophils to endothelium at sites of inflammation (38). ELAM-1 contains a lectin domain, an epidermal growth factor domain, and six complement-binding repeats (39). It is of interest that the migration of leukocytes across endothelium in response to inflammatory stimuli occurs primarily in small veins and venules (40). These are precisely the 


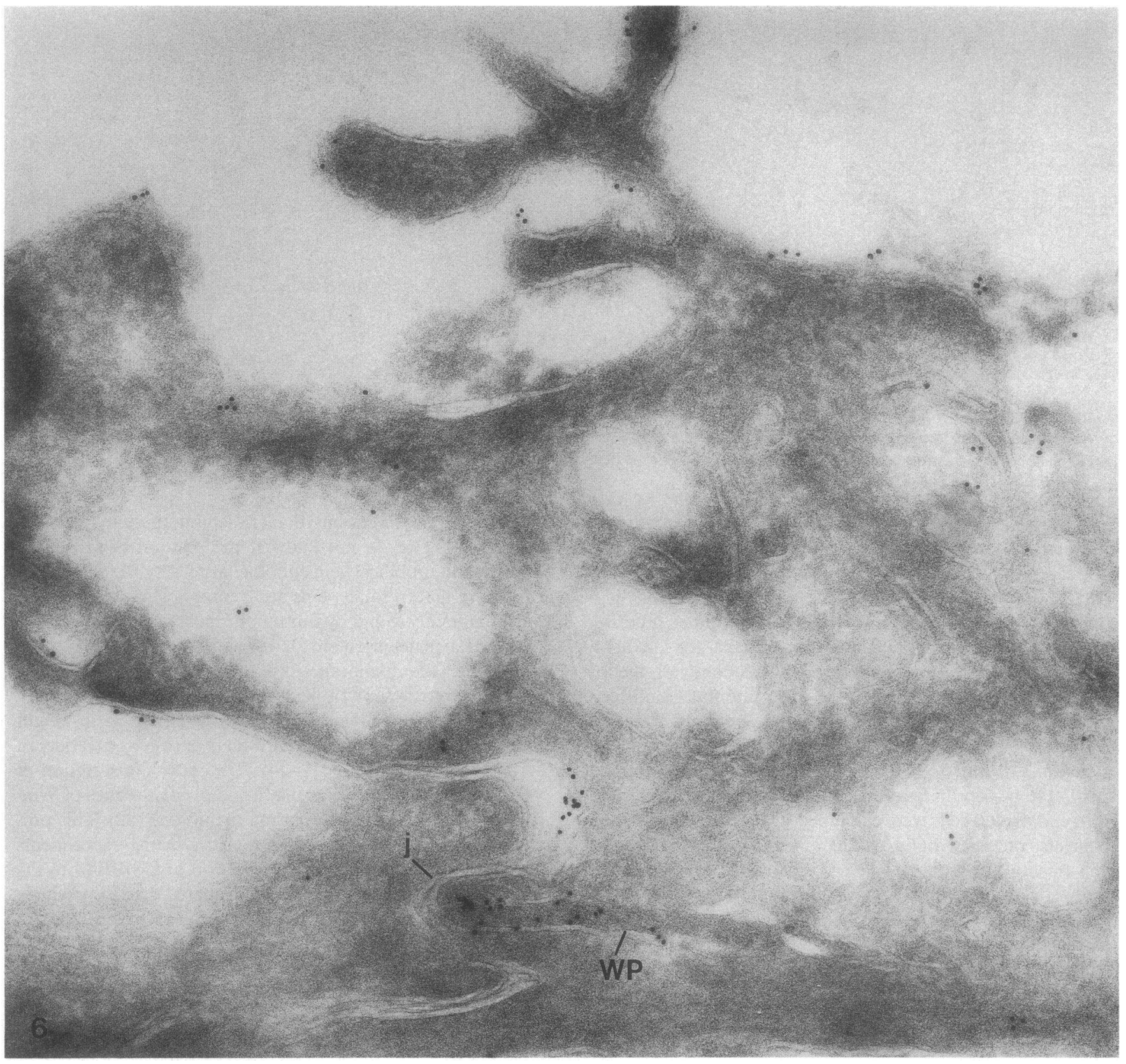

Figure 6. Higher magnification of two stimulated endothelial cells fixed 1 min after addition of histamine and then labeled with immunogold under conditions identical to those in Fig. 5. Note the marked disturbance of the cell surface with numerous microvilli and the expression of immunogold label for GMP-140 on the plasma membrane. There is a junctional complex $(j)$ between the two endothelial cells and the immunolabel is mainly on the apical surface rather than the lateral surface. An intracellular Weibel-Palade body $(W P)$ can also be seen. $\times 88,000$.

regions in endothelium where ELAM-1 (41) and GMP-140 (this study) are concentrated.

\section{Acknowledgments}

We thank Mary Torres, Janice Clements, Chris Titsworth, Charles Erdman, Kathleen O'Brien, and Yvonne Jacques for excellent technical assistance, and Karen Deatharage, Elaine Brown, and Denise Brewer for preparation of the manuscript. We are also grateful to Dr. Sandor Shattil (University of Pennsylvania, Philadelphia, PA) for providing us with the protocol for his ELISA procedure.

This research was supported by grants HL-34364 and HL-31610 from the National Institutes of Health. Dr. McEver is the recipient of Research Career Development Award HL-01733 from the National Institutes of Health.

\section{References}

1. McEver, R. P., and M. N. Martin. 1984. A monoclonal antibody to a membrane glycoprotein binds only to activated platelets. J. Biol. Chem. 259:9799-9804.

2. Hsu-Lin, S.-C., C. L. Berman, B. C. Furie, D. August, and B. Furie. 1984. A platelet membrane protein expressed during activation and secretion: studies using a monoclonal antibody specific for thrombin-activated platelets. J. Biol. Chem. 259:9121-9126.

3. Stenberg, P. E., R. P. McEver, M. A. Shuman, Y. V. Jacques, and D. F. Bainton. 1985. A platelet alpha-granule membrane protein (GMP-140) is expressed on the plasma membrane after activation. $J$. Cell Biol. 101:880-886.

4. Berman, C. L., E. L. Yeo, J. D. Wencel-Drake, B. C. Furie, M. H. Ginsberg, and B. Furie. 1986. A platelet alpha granule membrane protein that is associated with the plasma membrane after activation. 
Characterization and subcellular localization of platelet activation-dependent granule-external membrane protein. J. Clin. Invest. 78:130137.

5. Isenberg, W. M., R. P. McEver, M. A. Shuman, and D. F. Bainton. 1986. Topographic distribution of a granule membrane protein (GMP-140) that is expressed on the platelet surface after activation: an immunogold-surface replica study. Blood Cells (Berl.). 12:191-264.

6. Johnston, G. I., A. Kurosky, and R. P. McEver. 1989. Structural and biosynthetic studies of the granule membrane protein, GMP-140, from human platelets and endothelial cells. J. Biol. Chem. 264:18161823.

7. Beckstead, J. H., P. E. Stenberg, R. P. McEver, M. A. Shuman, and D. F. Bainton. 1986. Immunohistochemical localization of membrane and $\alpha$-granule proteins in human megakaryocytes. Application to plastic-embedded bone marrow biopsy specimens. Blood. 67:285293.

8. McEver, R. P., E. M. Bennett, and M. N. Martin. Identification of two structurally and functionally distinct sites on human platelet membrane glycoprotein IIb-IIIa using monoclonal antibodies. J. Biol. Chem. 258:5269-5275.

9. Jaffe, E. A., R. L. Nachman, C. G. Becker, and C. R. Minick. 1973. Culture of human endothelial cells derived from umbilical veins. Identification by morphologic and immunologic criteria. J. Clin. Invest. 52:2745-2756.

10. Slot, J. W., and H. J. Geuze. 1984. Gold markers for single and double immunolabeling of ultrathin cryosections. In Immunolabeling for Electron Microscopy. J. M. Polak and I. M. Varndell, editors. Elsevier, Oxford. 129.

11. Wiedmer, T., C. T. Esmon, and P. J. Sims. 1986. On the mechanism by which complement proteins C5b-9 increase platelet prothrombinase activity. J. Biol. Chem. 261:14587-14592.

12. Shattil, S. J., M. Cunningham, and J. A. Hoxie. 1987. Detection of activated platelets in whole blood using activation-dependent monoclonal antibodies and flow cytometry. Blood. 70:307-315.

13. Bray, P. F., J.-P. Rosa, G. I. Johnston, D. T. Shiu, R. G. Cook, C. Lau, Y. W. Kan, R. P. McEver, and M. A. Shuman. 1987. Platelet glycoprotein IIb. Chromosomal localization and tissue expression. $J$. Clin. Invest. 80:1812-1817.

14. Maruyama, I., C. E. Bell, and P. W. Majerus. 1985. Thrombomodulin is found on endothelium of arteries, veins, capillaries, and lymphatics, and on syncytiotrophoblast of human placenta. J. Cell Biol. 101:363-371.

15. Tabilio, A., J.-P. Rosa, U. Testa, N. Kieffer, A. T. Nurden, M. C. Del Canizo, J. Breton-Gorius, and W. Vainchenker. 1984. Expression of platelet membrane glycoproteins and $\alpha$-granule proteins by a human erythroleukemia (HEL) cell line. EMBO (Eur. Mol. Biol. Organ.) J. 3:453-459.

16. Tarentino, A. L., and F. Maley. 1974. Purification and properties of an endo- $\beta-N$-acetylglucosaminidase from streptomyces griseus. J. Biol. Chem. 249:811-817.

17. Weibel, E. R., and G. E. Palade. 1964. New cytoplasmic components in arterial endothelia. J. Cell Biol. 23:101-112.

18. Wagner, D. D., J. B. Olmsted, and V. J. Marder. 1982. Immunolocalization of von Willebrand protein in Weibel-Palade bodies of human endothelial cells. J. Cell Biol. 95:355-360.

19. Reinders, J. H., P. G. de Groot, M. D. Gonsalves, J. Zandbergen, C. Loesberg, and J. A. van Mourik. 1984. Isolation of a storage and secretory organelle containing von Willebrand protein from cultured human endothelial cells. Biochim. Biophys. Acta. 804:361-369.

20. Sporn, L. A., V. J. Marder, and D. D. Wagner. 1986. Inducible secretion of large, biologically potent von Willebrand factor multimers. Cell. 46:185-190.

21. Ewenstein, B. M., M. J. Warhol, R. I. Handin, and J. S. Pober. 1987. Composition of the von Willebrand factor storage organelle (Weibel-Palade body) isolated from cultured human umbilical vein endothelial cells. J. Cell Biol. 104:1423-1433.

22. Loesberg, C., M. D. Gonsalves, J. Zandbergen, C. Willems, W. G. van Aken, H. V. Stel, J. A. van Mourik, and P. G. de Groot. 1983. The effect of calcium on the secretion of factor VIII-related antigen by cultured human endothelial cells. Biochim. Biophys. Acta. 763:160-168.

23. Hamilton, K. K., and P. J. Sims. 1987. Changes in cytosolic $\mathrm{Ca}^{2+}$ associated with von Willebrand factor release in human endothelial cells exposed to histamine. Study of microcarrier cell monolayers using the fluorescent probe indo-1. J. Clin. Invest. 79:600-608.

24. Hattori, R., K. K. Hamilton, R. P. McEver, and P. J. Sims. 1988. Complement proteins $\mathrm{C} 5 \mathrm{~b}-9$ induce secretion of high molecular weight multimers of endothelial von Willebrand factor and translocation of granule membrane protein GMP-140 to the cell surface. J. Biol. Chem. 264:9053-9060.

25. Jaffe, E. A., L. W. Hoyer, and R. L. Nachman. 1973. Synthesis of antihemophilic factor antigen by cultured human endothelial cells. J. Clin. Invest. 52:2757-2764.

26. Nachman, R., R. Levine, and E. A. Jaffe. 1977. Synthesis of Factor VIII antigen by cultured guinea pig megakaryocytes. J. Clin. Invest. 60:914-921.

27. Sporn, L. A., S. I. Chavin, V. J. Marder, and D. D. Wagner. 1985. Biosynthesis of von Willebrand protein by human megakaryocytes. J. Clin. Invest. 76:1102-1106.

28. Phillips, D. R., I. F. Charo, L. V. Parise, and L. A. Fitzgerald. 1988. The platelet membrane glycoprotein IIb-IIIa complex. Blood. 71:831-843.

29. Fair, D. S., R. A. Marlar, and E. G. Levin. 1986. Human endothelial cells synthesize protein S. Blood. 67:1168-1171.

30. Stern, D., J. Brett, K. Harris, and P. Nawroth. 1986. Participation of endothelial cells in the protein C-protein S anticoagulant pathway. The synthesis and release of protein S. J. Cell Biol. 102:19711978.

31. Frazier, W. A. 1987. Thrombospondin. A modular adhesive glycoprotein of platelets and nucleated cells. J. Cell Biol. 105:625-632.

32. McNiff, J. M., and J. Gil. 1983. Secretion of Weibel-Palade bodies observed in extra-alveolar vessels of rabbit lung. J. Appl. Physiol. Respir. Environ. Exercise Physiol. 54:1284-1286.

33. Hattori, R., K. K. Hamilton, R. P. McEver, and P. J. Sims. 1988. A granule membrane protein, GMP-140, is a marker of von Willebrand factor secretion from endothelial cells. Blood. 72(Suppl 1):368a. (Abstr.)

34. George, J. N., E. B. Pickett, S. Saucerman, R. P. McEver, T. J. Kunicki, N. Kieffer, and P. J. Newman. 1986. Platelet surface glycoproteins. Studies on resting and activated platelets and platelet membrane microparticles in normal subjects, and observations in patients during adult respiratory distress syndrome and cardiac surgery. J. Clin. Invest. 78:340-348.

35. Johnston, G. I., E. B. Pickett, R. P. McEver, and J. N. George. 1987. Heterogeneity of platelet secretion in response to thrombin demonstrated by fluorescence flow cytometry. Blood. 69:1401-1403.

36. Wiedmer, T., B. Ando, and P. J. Sims. 1987. Complement C5b-9-stimulated platelet secretion is associated with a $\mathrm{Ca}^{2+}$-initiated activation of cellular protein kinases. J. Biol. Chem. 262:1367413681 .

37. Johnston, G. I., R. G. Cook, and R. P. McEver. 1989. Cloning of GMP-140, a granule membrane protein of platelets and endothelium: sequence similarity to proteins involved in cell adhesion and inflammation. Cell. 56:1033-1044.

38. Bevilacqua, M. P., J. S. Pober, D. L. Mendrick, R. S. Cotran, and M. A. Gimbrone, Jr. 1987. Identification of an inducible endothelial-leukocyte adhesion molecule, ELAM-1. Proc. Natl. Acad. Sci. USA. 84:9238-9242.

39. Bevilacqua, M. P., S. Stengelin, M. A. Gimbrone, Jr., and B. Seed. 1989. Endothelial-leukocyte adhesion molecule 1: an inducible receptor for neutrophils related to complement regulatory proteins and lectins. Science (Wash. DC). 243:1160-1165.

40. Cotran, R. S., and J. S. Pober. 1988. Endothelial activation: its role in inflammatory and immune reactions. In Endothelial Cell Biology in Health and Disease. N. Simionescu and M. Simionescu, editors. Plenum Publishing Corp., New York. 335-348.

41. Cotran, R. S., M. A. Gimbrone, Jr., M. P. Bevilacqua, D. L. Mendrick, and J. S. Pober. 1986. Induction and detection of a human endothelial activation antigen in vivo. J. Exp. Med. 164:661-666. 